\title{
John Emerich, Lord Acton
}

THAT with Lord Acton England lost the last of a generation 1 of great historians has not been fully recognised in the obituary notices which appeared after his death on 19 June. There was a fascination that arrested attention in his championship of the losing side in a Roman controversy which has now passed into history. As for the later career of the dangerously learned layman who had ventured into an unequal struggle there was not very much of which the public could judge. By Mr. Gladstone's recommendation Sir John Acton was raised to the upper house, and he is known to have exercised a strong influence upon that statesman. When in $\mathbf{1 8 9 2}$ he accepted an office in the royal household, this was understood as a mark of respect paid not less to learning than to political fidelity; and there seemed nothing incongruous, three years later, in the nomination of a lord-in-waiting to the Regius professorship of modern history at Cambridge. Beyond these few dates in Lord Acton's life we have read of the fame of his erudition and of the immense library which he accumulated. His biographers have been perplexed by the disparity between the promise and the performance, and have endeavoured to explain why it was that he never attained the stature of a great statesman. Was it that when the Vatican Council closed a period in his career he was reluctant to enter upon a second and perhaps a not less fruitless campaign? or was it that he chose rather to be the trusted counsellor of those who took a leading part in English politics and to remain silent while giving a decisive momentum to the course of policy which he approved? On such questions it would be irrelevant to speculate in this Review. We are here solely concerned with his work as an historian.

The grandson of a Neapolitan prime minister on one side and of a German duke, who was also a French ambassador, on the other, great-grand-nephew of the last prince-archbishop of Mainz, nephew of a cardinal, stepson of an English foreign secretary and leader of the liberal party in the house of lords-connected by marriage with a noble Bavarian house-Lord Acton was placed in an unequalled position for viewing modern history in a wide range. 
He was as much at home by the Tegernsee, or beyond the Austrian border, at Munich or Cannes, as in London or at Trinity College, Cambridge. With the necessary foreign languages he was perfectly familiar, and he knew the mind of continental nations and the springs of their politics and their religious movements with an intimacy possible only to one who lived much of his life in the inner circles of their society. Devoting himself to history, he read unceasingly and in the widest range, and he was reputed to be the best-read man of his time. But when urged to write a book which should take its place in a famous German historical series, he resisted the pressure. He never wrote a book. He never, we believe, until he was sixty, delivered a lecture. His writings must be sought out, if that is possible, in the two magazines which he edited as a young man, and in the compositions of his mature age which he published in various periodicals, and of which some of the most characteristic specimens appeared in the earlier volumes of this Review. ${ }^{2}$ When to these we have added the introduction which he contributed to Mr. Burd's edition of the 'Principe' of Machiavelli, ${ }^{3}$ and his inaugural lecture at Cambridge, ${ }^{4}$ we have nearly completed the tale of work printed under his name..$^{5}$ Evidently then it is not by quantity but by quality that he should be judged, and it is difficult for those who knew him well to avoid allowing his brilliant personality to be taken into the scales. In conversation he bad few superiors; and with all his wit and lightness of touch he always left one with the sense of a deep reserve not drawn upon. It was not that he was allusive so much as that he took for granted the knowledge of a world of facts which it seemed unnecessary for him to mention. The same impressiveness accompanied Lord Acton in his writinge. Even when his erudition is most fully displayed, one feels that he is imparting only a few

1 Two articles in the Home and Foreign Review on 'Cardinal Wiseman' and on "Conflicts with Rome" are attributed to him in the Times of 20 June last. 'They appeared in i. 501-20 (Oct. 1862) and iv. 667-90 (April 1864). It would be easy to add others from that Review and from the earlier Rambler.

$2 A$ list of these will be found below, on p. 699. Among other articles which have been publicly attributed to him wo may specially mention 'The Borgias and their latest Historian,' in the North British Review for January 1871 (liii. 351-367), and 'Wolsey and the Divorce of Henry VIII,' 'in the Quarterly Review for January 1877 (cxliii. 1-51).

Oxford, 1891.

4 A Lecture on the Study of History delivered at Cambridge 11 June 1895 (London, 1896).

3 In the time of the Vatican council two German pamphlets appeared bearing his name, Sendschreiben an einen aeutschen Bischof des vaticanischen Concils, Sept. $18 \% 0$ (Nördlingen), and Zur Geschichte des vaticanischen Conciles (Munich, 1871). The latter appeared anonymously in English in the North British Review for October 1870 (liii. 183-229). Mention may also be made of four remarkable letters to the Times of 9, 24, and 30 Nov. and 12 Dec. 1874 on 'The Vatican Decrees.' The second of these is full of bistorical matter. Lord Acton also edited an undated excernt from Harps. field's Narrative of the Divoree [1891?] 
chosen examples out of an ampler store. If it be permitted to assume the authorship of some articles which appeared about thirty years ago and were then currently attributed to him, we shall judge that his manner was then less severely restrained than it became in later years. The conciseness which he studied added force and pregnancy to a style which had never failed in distinction. $\mathrm{He}$ always chose the right word, the happy phrase; and his simplest. sentences told because they were charged with more meaning than. first caught the eye.

It has been disputed whether his strength lay in the mastery of materials or in the grasp of principles; and some have thought. that his volume of knowledge was too broad to admit of depth. We shall challenge this opinion later on. For the moment the stress must lie upon his amazing familiarity not merely with the literature of history but with the texts themselves. To those who heard his memorable inaugural lecture at Cambridge, in which he. seemed to limit the value of history to the last four centuries, it may be a paradox that to others he appears just as intimate with the thirteenth century and the politics of the Avignon popes. But these dates are far from marking the earlier boundary of his reading or of his interest. He once indicated what he held to be the decisive dates in the development of the study of history in Germany. It was the work of Niebuhr on the earliest Roman history and of Boeckh on Greek inscriptions that led the way. The latter's

'Public Economy of the Athenians' is almost the only history produced before the critical epoch which still stands, unshaken and erect. The critical epoch lies between 1824 and 1828. . . .

A new art of employing authorities came in with Ranke in 1824. Müller's 'Introduction to the Science of Mythology' quickly followed: Gieseler and Neander began their histories of the Church; and Menzel, after an inferior book on the middle ages, published the first volume of what was long the best modern history of Germany. Niebuhr prepared the new edition which is the pillar of his fame, in 1827 ; and in 1828 Stenzel adapted to the Gregorian period the canons of criticism which Ranke had made obligatory on every serious writer. These seven or eight works were the symptom of a great transition. ${ }^{6}$

Boeckh and Niebuhr and Ottfried Müller laid in Lord Acton's opinion the landmarks of a new period in historical study; they were of no less significance for the modern historian than the work of Ranke. Lord Acton had attended the lectures of Boeckh, Ranke, Riehl, and many more of the same generation, already aging when he heard them. Doellinger he knew on terms of the closest friendship for the greater part of his life. From these he learned to look upon all history as his province and to neglect no department of

- 'German Schools of History,' in the Engl. Hist. Rev. i. 12 seq. (1886). 
it because it interested him less directly than others. The influence of Hegel, in which may be seen the ultimate motive of the Tübingen school, he delighted to explore; but he was not blind to the spiritual insight of Neander, " the ponderous professor of pectoral theology.' 7 When he had to commemorate the great Cambridge historians, the names he selected were those of Maine, Lightfoot, and another professor, not of history, happily still among us. Of the exactness of his minute reading it would be a needless task to collect examples. We could adduce them as easily from the texts of early church history, or of the twelfth, thirteentb, or fourteenth century, as from those of later times concerning which his minute familiarity was notorious. He has been credited with a marvellous memory, and this certainly came out conspicuously in his conversation. But his power of citing the appropriate text was artificially assisted by the habit which he early formed of making written extracts of whatever struck him in his reading. These selections, made on slips of paper of a uniform size, were arranged and classified and stored in a prodigious series of boxes and drawers. On the advantages of such a method it is unnecessary to insist, and many laborious students may well envy the ease and security with which Lord Acton compressed the cream of his reading into compartments and was able to produce it at demand. But the drawbacks are also plain. They can be illustrated from the copious notes appended to the Cambridge inaugural lecture, which do not as a rule explain the text, but rather give suggestions of the mental process by which the writer was conducted to his end, suggestions however which would not of necessity lead a duller mind on to the same course of thought. He would not be beholden, even at a distance, to another without making express acknowledgment of the debt.

This practice of persistent annotation and decoction gave Lord Acton exceptional advantages as a critic. For his reading was so wide that he had only to open the proper receptacles to find nearly all that he required to substantiate and strengthen the points he wished to maintain. It is this fulness of equipment that strikes one first of all in reading any criticism by him. While he never assumed a pose of superiority, but rather seemed bent on showing how respectfully he appreciated the merits of the author of whom he treated, the impression left was that he wrote from a higher level of knowledge and that he had it in his power to support or demolish more than he thought appropriate to the present purpose. In force and stimulus his reviews are one and all complete. Sometimes their learning is almost oppressive, but this is not in the least for effect.

No scrupulous and self-respecting writer will speak his mind or say things that challenge inquiry unless the proof is prompt. To relieve his

' English Historical Review, iii. 776 (1888). 
text of the burden of incessant quotation, he must understate his meaning and lose in definiteness and precision what he gains in lightness. His chisel is necessarily blunted, and he cannot work in high relief. ${ }^{8}$

Therefore Lord Acton preferred even to overcharge his exposition with authorities rather than to risk doing injustice to the matter in hand. It would not be true that he dealt with the modern authors whom he criticised quite without reserve. Much he concealed under a grave irony, but his indirect fashion of exposing error or incompetence was apt to elude, and he left the hasty reader in the belief that he approved more than he actually did approve. It was the exception when he said out plainly that the work of a middling craftsman was not to be commended. The question of adequacy was left to be judged by a choice array of examples, neatly set side by side; but the sentence, unless in cases of ethical derangement, was undelivered. 'It is agreed,' he admitted, 'that a critic says much less than he means, and with this provision against misconstruction and the perils of understatement I may safely say that the methods of this book would be fatal to history.' That was a rare avowal. As a rule Lord Acton was too kindhearted to be a good critic in the common way of criticism. He once remarked of a certain author, ' $I$ had promised ' him 'to review the first volumes, and they produced the flimsiest paper I ever wrote. I sent him a list of the mistakes in the notes, about sixty in the two first volumes; and that left me nothing worth saying in print.' But if Lord Acton's reviews of books are not so helpful in guiding us to the value of the book dealt with as are those of many men of vastly inferior powers and attainments, they are as contributions to the literature of the subject itself, with hardly an exception, permanent achievements of the finest quality.

Lord Acton's erudition embraced all history, but in the maturity of his years he more and more devoted bimself to the seed-time of the problems of the present day. In other fields he remained better than most specialists, but on his chosen ground he stood quite by himself.

All that can be known of Caesar or Charlemagne, or Gregory VII, would hold in a dozen volumes; a library would not be sufficient for Charles V or Louis XVI. Extremely few of the ancients are really known to us in detail, as we know Socrates, or Cicero, or St. Augustine. But in modern times, since Petrarca, there are at least two thousand actors on the public stage whom we see by the revelations of private correspondence. Besides letters that were meant to be burnt, there are a man's secret diaries, his autobiography and table-talk, the recollections of his friends, self-betraying notes on the margins of books, the report of a trial if he is a culprit, and the evidence for beatification if he is a saint.

\footnotetext{
s Engl. Hist. Rev. ii. 572 seq. ,1887).
} 
Here we are on a different footing, and we practise a different art when dealing with Phocion or Dunstan, and with Richelieu or Swift. In one case we remain perforce on the surface of character, which we have not the means of analysing: we have to be content with conjecture, with probable explanations and obvious motives. We must constantly allow the benefit of the doubt, and reserve sentence. The science of character comes in with modern history. ${ }^{9}$

\section{In another connexion he said :}

To men in general I would justify the stress I am laying on modern history, neither by urging its varied wealth, nor the rupture with precedent, nor the perpetuity of change and increase of pace, nor the growing predominance of opinion over belief, and of knowledge over opinion, but by the argument that it is a narrative told of ourselves, the record of a life which is our own, of efforts not yet abandoned to repose, of problems that still entangle the feet and vex the hearts of men. Every part of it is weighty with inestimable lessons that we must learn by experience and at a great price, if we know not how to profit by the example and teaching of those who have gone before us, in a society largely resembling the one we live in. Its study fulfils its purpose even if it only makes us wiser, without producing books, and gives us the gift of historical thinking, which is better than historical learning. It is a most powerful ingredient in the formation of character and the training of talent, and our historical judgments have as much to do with our hopes of heaven as public or private conduct. Convictions that have been strained through the instances and the comparisons of modern times differ immeasurably in solidity and force from those which every new fact perturbs, and which are often little better than illusions or unsifted prejudice. ${ }^{10}$

From this he proceeds at once to the declaration: "The first of human concerns is religion, and it is the salient feature of the modern centuries.' That is why they are worthy of study. It is not the question here whether this exclusive claim was right or wrong: it is enough to state the reason for which Lord Acton called his Cambridge audience to accompany him in his path. The same motive which urged him as a young man to venture on the troubled sea of ecclesiastical controversy led him in later years to uphold the virtues of modern history. He approached the subject from the point of view of theology or of ethics; it is not easy to say which, for the two were to him in this relation inextricably associated. Never did he speak with more impressiveness than when, in the simplest words, he begged his hearers

to see that the action of Christ who is risen on mankind whom He redeemed fails not, but increases; that the wisdom of divine rule appears not in the perfection but in the improrement of the world; and that achieved liberty is the one ethical result that rests on the converging and combined conditions of advancing civilisation. Then you will understand

9 'Doellinger's Historical Work,' ibid. v. 724 seq: (1890).

10 The Study of History, p: 19 seq. 
what a famous philosopher said, that History is the true demonstration of Religion. ${ }^{11}$

Again he warned them against doctrines of the fashionable school of historians :

The weight of opinion is against me when I exhort you never to debase the moral currency or to lower the standard of rectitude, but to try others by the final maxim that governs your own lives, and to suffer no man and no cause to escape the undying penalty which history has the power to inflict on wrong. The plea in extenuation of guilt and mitigation of punishment is perpetual. At every step we are met by arguments which go to excuse, to palliate, to confound right and wrong, and reduce the just man to the level of the reprobate. ${ }^{12}$

In another place he connects his teaching with a definite political principle :

A liberal who thinks his thought out to the end without flinching is forced to certain conclusions which colour to the root every plan and scene of universal history. He believes in upward progress, because it is only recent times that have striven deliberately, and with a zeal according to knowledge, for the increase and security of freedom. He is not only tolerant of error in religion, but is specially indulgent to the less dogmatic forms of Christianity, to the sects which have restrained the churches. $\mathrm{He}$ is austere in judging the past, imputing not error and ignorance only, but guilt and crime, to those who, in the dark succession of ages, have resisted and retarded the growth of history, which he identifies with the cause of morality, and the condition of the reign of conscience. ${ }^{13}$

This is stated as a 'political party question' which is 'decisive.' Lord Acton held to it to the end, just as in early life he had opposed the dogma of infallibility because he was convinced that it stereotyped the Syllabus. Yet he admitted that liberty

resembles the camel, and enjoys more definitions than any object in nature; ${ }^{14}$ that it is an idea of which there are two hundred definitions, and that this wealth of interpretation has caused more bloodshed than anything except theology..$^{15}$

On the other hand his political attachment was so sincere and whole-hearted, and his own party principles were so identified in his mind with the cause of liberty and morality, that he believed absolutely that all genuine progress led inevitably to, and was bound up with, them.

It has been maintained that the philosophy of history, like the

"The Study of History, p. 31 seq.

12 Ibid. p. 63 seq.

14 'Doellinger's Historical Work,? ubi supra, p. $718 \mathrm{seq}$.

"4 Engl. Hist. Rev. iii. 798 (1888).

is The Study of History, p. 32. 
philosophy of religion, is a subject invented for the employment of those who are neither philosophers nor historians. If this be the rule, Lord Acton was the exception. In philosophy, if not profound, he was extraordinarily well equipped; in history he was both, without a rival, and that which gives measure and weight to his judgments is the thought which inspires them and the ethical force by which they are governed. He went to Cambridge at a time when there was a danger lest the professorship of modern history should be too exclusively directed towards the philosophical motives and the political drift of history. With this tendency he had so much in common that he made no break in the tradition of the chair. But he controlled it by a firm and severe insistence on the necessity of an exact knowledge of facts both in their wider range and in the smallest details; and while his zeal and painstaking made themselves felt everywhere, his influence was perhaps even stronger among the teachers of history than among his undergraduate pupils. In this way he did a service to the study of history in his university the immense value of which is recognised by those who are in a position to judge from witnin. For one who has not that advantage it would be impertinent to say more; but no attempt to indicate, however faintly, the characteristics or Lord Acton's work could omit to refer to his courageous decision to pass at the age of sixty from speculation to practice, and to allow one circle of students to know something of the plenitude of his powers.

Reginald L. Poole.

\section{List of Lord Acton's Contributions to the 'English Historical Review.'}

German Schools of History, vol. i. pp. 7-42, 1886.

Doellinger's Historical Work, vol. v. pp. 702-744, 1890.

Wilhelm von Giesebrecht, vol. v. pp. 306-310, 1890.

R. Flint's Historical Philosophy in France and French Belgium and Switzerland, vol. x. pp. 108-113, 1895.

H. C. Lea's History of the Inquisition of the Middle Ages, vol. iii. pp. 773-788, 1888.

M. Creighton's History of the Papacy during the Period of the Reformation, III. Iv., vol. ii. pp. 571-581, 1887.

E. de Broglie's Mabillon et la Societe de l'Abbaye de Saint-Germain-des-Pres, vol. ii. pp. 585-592, 1888.

H. M. Stephens's History of the French Revolution, Ir., vol. vii. pp. 382-384, 1892.

J. R. Seeley's Short History of Napoleon and J. C. Ropes's The First Napoleon, vol. ii. pp. 593-603, 1887.

J. F. Bright's History of England, 1837-1880, vol. iii. pp. 798-809, 1888.

J. Bryce's American Commonwealth, vol. iv. pp. 388-396, 1889. 